\title{
Feasibility of a provincial voluntary reporting system for work-related asthma in Ontario
}

\author{
Teresa To PhD ${ }^{1}$, Susan M Tarlo MB BS FRCPC ${ }^{2}$, Susan McLimont BA ${ }^{3}$, Ted Haines MD MSc FRCPC CCFP4, \\ D Linn Holness MD MSc FRCPC ${ }^{5}$, M Diane Lougheed MD MSc FRCPC FCPP6, \\ Gary M Liss MD MS FRCPC 7 , Lisa Cicutto PhD ACNP8
}

T To, SM Tarlo, S McLimont, et al. Feasibility of a provincial voluntary reporting system for work-related asthma in Ontario. Can Respir J 2011;18(5):275-277.

OBJECTIVE: The Ontario Work-Related Asthma Surveillance System: Physician Reporting (OWRAS) Network was established in 2007 to estimate the prevalence of work-related asthma (WRA) in Ontario, and to test the feasibility of collecting data for cases of WRA from physicians voluntarily.

METHODS: More than 300 respirologists, occupational medicine physicians, allergists and primary care providers in Ontario were invited to participate in monthly reporting of WRA cases by telephone, postal service or e-mail.

RESULTS: Since 2007, 49 physicians have registered with the OWRAS Network and, to date, have reported 34 cases of occupational asthma and 49 cases of work-exacerbated asthma. Highly reactive chemicals were the most frequently reported suspected causative agent of the 108 suspected exposures reported.

CONCLUSION: Despite the challenge of enlisting a representative sample of physicians in Ontario willing to report, the OWRAS Network has shown that it is feasible to implement a voluntary reporting system for WRA; however, its long-term sustainability is currently unknown.

Key Words: Occupational diseases; Physician reporting; Population surveillance; Work-related asthma

W ork-related asthma (WRA) is the most frequent type of workrelated lung disease, and cases are classified as either occupational asthma (OA) or work-exacerbated asthma (WEA). OA has been clearly defined for several years, whereas different definitions of WEA have been proposed depending on the type of study undertaken to define the condition. OA and WEA are difficult to differentiate in clinical practice, and individuals with $\mathrm{OA}$ may experience a greater improvement of their asthmatic condition after removal from exposure than those with WEA (1). Although the rate of job change or work loss was higher in OA subjects, Labarnois et al (2) reported that the rates of work disruption and income loss were similar between subjects with OA and those with WEA, indicating that WEA and OA may have a similar economic impact.

Currently, WRA represents a major health challenge that, if left unrecognized, may lead to long-term disability and adverse social and economic impacts $(3,4)$. Several countries have developed surveillance programs for WRA, such as the Surveillance of Work-Related and Occupational Respiratory Disease (SWORD) in the United Kingdom, the Sentinel Event Notifications System for Occupational Risks (SENSOR) in the United States, and the Surveillance of Australian Workplace Based Respiratory Events (SABRE) in Australia, which provide estimates of the disease burden among the workforce, identify triggers and monitors trends over time using standard definitions that can be used across jurisdictions (5-11). While most of these programs report challenges to complete case ascertainment (eg, underreporting), analysis of the distribution of WRA across jurisdictions,

\section{La faisabilité d'un système provincial de déclaration volontaire de l'asthme professionnel en Ontario}

OBJECTIF : Le réseau OWRAS de surveillance de l'asthme professionnel déclaré par les médecins en Ontario a été créé en 2007 afin d'évaluer la prévalence d'asthme professionnel (AP) en Ontario et de vérifier la faisabilité que les médecins colligent volontairement des données à l'égard des cas d'AP.

MÉTHODOLOGIE : Plus de 300 pneumologues, médecins du travail, allergologues et dispensateurs de soins primaires de l'Ontario ont été invités à participer à la déclaration mensuelle des cas d'AP par téléphone, par la poste ou par courriel.

RÉSULTATS : Depuis 2007, 49 médecins se sont inscrits au réseau OWRAS et, jusqu'à maintenant, ont déclaré 34 cas d'asthme professionnel et 49 cas d'asthme exacerbé par le travail. Des produits chimiques hautement réactifs étaient les agents causaux qu'on croyait les plus souvent responsables de 108 expositions présumées déclarées.

CONCLUSION : Malgré la difficulté de faire participer un échantillon représentatif de médecins de l'Ontario à la déclaration, le réseau OWRAS a démontré qu'il est faisable d'implanter un système de déclaration volontaire sur l'AP. On n'en connaît toutefois pas la pérennité.

industries, and occupational and sociodemographic groups can highlight potential risk factors or at-risk groups to target with further investigation and possible prevention programs.

Currently, there is no comprehensive surveillance of WRA in Ontario, despite legislation that mandates employer reporting of any occupational disease or illness (12). Statistics on compensated injuries and illnesses in Ontario are collected separately by the Ontario Workers Safety and Insurance Board (WSIB), which promotes workplace health and safety, and provides workers' compensation for insured workplaces. Because not all cases of WRA are submitted to the WSIB, and not all claims result in compensation, this is probably not sufficiently comprehensive for surveillance purposes.

The Ontario Work-Related Asthma Surveillance System: Physician Reporting (OWRAS) Network was established in 2007 to estimate the prevalence of WRA in Ontario, test the feasibility of physicians voluntarily reporting WRA cases seen in their practice and raise awareness about WRA among providers.

\section{METHODS}

Membership to the OWRAS Network was promoted through targeted professional organizations and associations using multiple forms of media: presentations at conferences and meetings, informative articles in newsletters and hotlinks on their websites. To increase membership, a modified Dillman method (13) that consisted of sending an invitation letter, brochure and postage paid self-addressed postcard (used to indicate whether they were interested in participating) to

${ }^{1}$ The Hospital for Sick Children, University of Toronto and Institute for Clinical Evaluative Sciences; ${ }^{2}$ Toronto Western Hospital and University of

Toronto; ${ }^{3}$ The Hospital for Sick Children, Toronto; ${ }^{4} \mathrm{McM}$ aster University, Hamilton; ${ }^{5} \mathrm{St}$ Michael's Hospital and University of Toronto,

Toronto; ${ }^{6}$ Queen's University, Kingston; ${ }^{7}$ Ontario Ministry of Labour and University of Toronto; ${ }^{8}$ University of Toronto, Toronto, Ontario

Correspondence and reprints: Dr Teresea To, The Hospital for Sick Children, 555 University Avenue, Toronto, Ontario M5G 1 X8.

Telephone 416-813-8498, fax 416-813-5979, e-mail teresa.to@sickkids.ca 


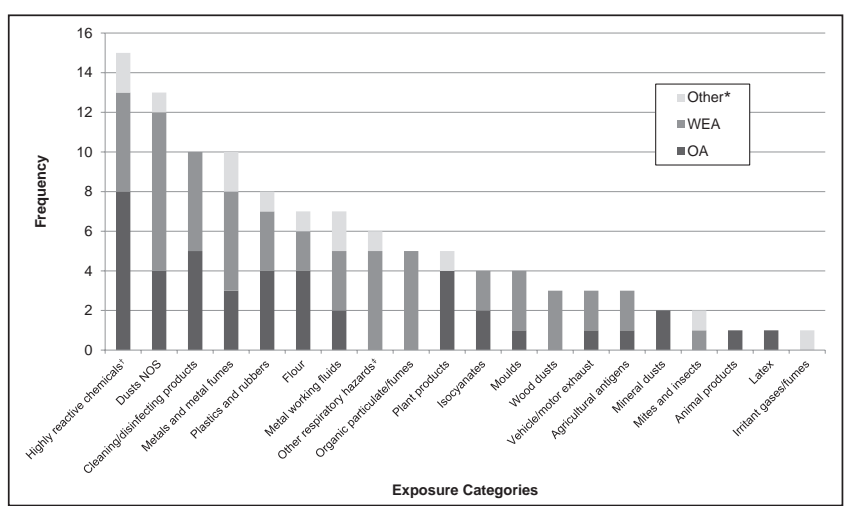

Figure 1) Suspected exposures reported to the Ontario Work-Related Asthma Surveillance System: Physician Reporting network between January 2007 and March 2010 according to disease type. *Includes bronchitis, rhinitis or skin changes; ${ }^{\dagger}$ Examples include anhydrides, amines, reactive dyes, glues, biocides, etc; ${ }^{*}$ Examples include cold environment (ie, fridge or freezer) and exertion (trigger). NOS Not otherwise specified; OA Occupational asthma; WEA Work-exacerbated asthma

all respirologists $(n=205)$, allergists $(n=36)$, occupational medicine specialists $(n=45)$, and other physicians with interest in occupational diseases $(n=45)$ in Ontario identified from the Canadian Medical Directory database was used.

Each participating physician was asked to complete a report following a patient visit for each confirmed or suspected case of OA and WEA, as well as work-related bronchitis, rhinitis or skin changes using a tear-off sheet attached to a dropbox placed in their office. Each month, a reminder postcard with a postage-paid, self-addressed envelope was sent to all physicians who had not submitted a report.

Physicians were provided with definitions, also available on the front of the dropbox. OA was defined as cases without an existing asthma condition in whom asthma symptoms develop after exposure to a sensitizer found at work, while WEA was defined as cases with an existing asthma condition in whom the severity or frequency of asthma symptoms increases after exposure to a nonspecific trigger found in the workplace. Patient initials and year of birth were recorded for each case to assist in identifying duplicate reports. Physicians also provided the following information for each case: current occupation or occupation responsible; suspected exposure(s); symptoms (wheeze, chest tightness, and/or cough); smoking status; and whether a claim had been submitted to the WSIB. On receiving the reports, occupations were classified according to the National Occupational Classification for Statistics (14), and exposures reported were classified into categories based on those used in the asthma-specific job exposure matrix (15).

The study methodology and materials were reviewed and approved by the Research Ethics Board at The Hospital for Sick Children Research Institute, Toronto, Ontario.

\section{RESULTS}

Since January 2007, 49 physicians have registered with the OWRAS Network (excluding members of the authors' research group who see WRA patients by referral to tertiary clinics), 42 of whom were recruited using the targeted mailout strategy. They include 27 respirologists $(55.1 \%)$, four allergists $(8.2 \%)$, three occupational medicine physicians (6.1\%), 14 general practitioners/family physicians with an interest in occupational diseases $(28.6 \%)$ and one internist. As expected, the initial uptake of reporting was slow but, on average, reporting was steady, with $80 \%$ to $90 \%$ of report cards returned each month.

Between January 2007 and March 2010, a total of 34 cases of OA, 49 cases of WEA, three cases of work-related bronchitis, four cases of work-related skin changes and 18 cases of work-related rhinitis have been reported. Of the 83 cases of WRA reported by physicians, $9.6 \%$
TABLE 1

Reported occupations responsible for cases of occupational asthma (OA) and work-exacerbated asthma (WEA) for the most highly reported suspected exposures

\begin{tabular}{|c|c|c|}
\hline \multirow{2}{*}{$\begin{array}{l}\text { Main } \\
\text { exposure* }\end{array}$} & \multicolumn{2}{|c|}{ Reported occupation responsible (listed alphabetically) ${ }^{\dagger}$} \\
\hline & OA cases & WEA cases \\
\hline $\begin{array}{l}\text { Highly } \\
\text { reactive } \\
\text { chemicals }^{\ddagger}\end{array}$ & $\begin{array}{l}\text { Automotive assembly worker } \\
\text { Forklift truck operator } \\
\text { Glass worker } \\
\text { Health care aide } \\
\text { Heavy equipment mechanic } \\
\text { Paper cup maker } \\
\text { Toy maker }\end{array}$ & $\begin{array}{l}\text { Hardware store clerk } \\
\text { Motor assembler }\end{array}$ \\
\hline $\begin{array}{l}\text { Dusts not } \\
\text { otherwise } \\
\text { specified }\end{array}$ & $\begin{array}{l}\text { Carpenter } \\
\text { Cleaner } \\
\text { Military police officer } \\
\text { Warehouse worker }\end{array}$ & $\begin{array}{l}\text { Call centre agent } \\
\text { Electrician } \\
\text { Furniture assembler and } \\
\text { upholsterer } \\
\text { Refrigeration technician } \\
\text { School custodian }\end{array}$ \\
\hline $\begin{array}{l}\text { Cleaning/ } \\
\text { disinfecting } \\
\text { products }\end{array}$ & $\begin{array}{l}\text { Food and beverage } \\
\text { processing machine } \\
\text { operator } \\
\text { Laundry worker } \\
\text { Shipper-receiver } \\
\text { Waste management worker }\end{array}$ & $\begin{array}{l}\text { Cleaner } \\
\text { House cleaner } \\
\text { Packer for wood products } \\
\text { Playground worker }\end{array}$ \\
\hline $\begin{array}{l}\text { Metals and } \\
\text { metal fumes }\end{array}$ & $\begin{array}{l}\text { Cheese factory worker } \\
\text { Secretary }\end{array}$ & $\begin{array}{l}\text { Assembly line general labourer } \\
\text { Urban transit maintenance } \\
\text { worker } \\
\text { Welder }\end{array}$ \\
\hline Flour & $\begin{array}{l}\text { Baker } \\
\text { Bakery labourer } \\
\text { Cheese factory worker }\end{array}$ & Cook \\
\hline $\begin{array}{l}\text { Other } \\
\text { respiratory } \\
\text { hazards }^{\S}\end{array}$ & & $\begin{array}{l}\text { Meat cutter } \\
\text { Meat packer } \\
\text { School custodian } \\
\text { Waitress }\end{array}$ \\
\hline $\begin{array}{l}\text { Metal working } \\
\text { fluids }\end{array}$ & $\begin{array}{l}\text { Machinist } \\
\text { Shipper-receiver }\end{array}$ & $\begin{array}{l}\text { Machinist } \\
\text { Metal fabrication worker } \\
\text { Metal products salesman }\end{array}$ \\
\hline $\begin{array}{l}\text { Plastics and } \\
\text { rubber }\end{array}$ & $\begin{array}{l}\text { Bakery labourer } \\
\text { Carpenter } \\
\text { Toy maker }\end{array}$ & \\
\hline $\begin{array}{l}\text { Organic } \\
\text { particulate/ } \\
\text { fumes }\end{array}$ & Bakery labourer & $\begin{array}{l}\text { Food and beverage processing } \\
\text { machine operator } \\
\text { Grain elevator operator } \\
\text { Refinery operator }\end{array}$ \\
\hline $\begin{array}{l}\text { Plant } \\
\text { products }\end{array}$ & $\begin{array}{l}\text { Bakery labourer } \\
\text { Farmer } \\
\text { Food and beverage } \\
\text { processing machine } \\
\text { operator }\end{array}$ & Farmer \\
\hline
\end{tabular}

${ }^{\star}$ Exposure categories based on those used in the Asthma-specific Job Exposure Matrix (15); ' Occupations classified according to the National occupation classification for statistics manual (14); ${ }^{\ddagger}$ Examples include anhydrides, amines, reactive dyes, glues, biocides, etc; ' ${ }^{\S}$ xamples include cold environment (ie, fridge or freezer) and exertion (trigger); "Other than latex and flour

$(n=8)$ were submitted to the WSIB for claims, and all but one were for OA. To date, 108 suspected exposures causing ill-health/sickness have been identified by the reporting physicians. Highly reactive chemicals, including anhydrides, amines, reactive dyes, glues, biocides, etc, are the most frequently reported suspected causative agents (Figure 1). The occupations reported as responsible for these cases of OA were assemblers and machine operators in manufacturing, construction trades, transport and equipment operators, and assisting occupations in support of health services (Table 1). Nonspecified dust exposure was 
the second most frequent suspected agent to cause OA and WEA. The occupations responsible were listed as construction and electrical trades, assemblers in manufacturing, cleaners and occupations in protective services.

\section{DISCUSSION}

In the early 1900s, surveillance of the health of workers was limited to medical examinations for certain categories of workers and for specific occupational hazards. It was not until the 1980s that preventive occupational medicine and occupational health services were implemented in some settings such as large corporations. Challenges to establishing surveillance systems for $\mathrm{OA}$ are shared by most programs. The major challenges are the lack of a uniform definition, incomplete (underreporting) case ascertainment and physicians' low participation rate. Despite the challenges, some of these occupational disease and injury surveillance efforts facilitated provider-based surveillance of workrelated conditions and enhanced the uniformity of reporting. For example, the US SENSOR promotes a convenient way of reporting in which physicians can call a number to report a case of OA (16). However, surveillance systems tend to underestimate the incidence of occupational respiratory diseases. For example, in both Projet Pulmonaire Sentinelle (PROPULSE) in Quebec and Observatoire National De Asthmes Professionnels (ONAP) in France, there were twice as many $\mathrm{OA}$ cases identified through the schemes as those reported through workers' compensation. One of the biggest challenges in disease surveillance is in maintaining the enthusiasm of participating physicians over time. Provider participation and compliance are important to the success of any surveillance scheme. The highest participation rates are in schemes such as the SWORD in the United Kingdom which, although voluntary, do not have stringent case definition requirements and are anonymous. Therefore, it may be argued that lack of a case definition may improve compliance of reporting by providers. Conversely, the use of a surveillance case definition (as in SENSOR) facilitates provider-based surveillance of work-related conditions and enhances the uniformity of reporting nationally.

\section{REFERENCES}

1. Lemiere C. Occupational and work-exacerbated asthma: Similarities and differences. Exp Rev Respir Med 2007;1:43-7.

2. Larbanois A, Jamart J, Delwiche JP, Vandenplas O.

Socioeconomic outcome of subjects experiencing asthma symptoms at work. Eur Respir J 2002;19:1107-13.

3. Vandenplas O, Toren K, Blanc P. Health and socioeconomic impact of work-related asthma. Eur Respir J 2003;22:689-97.

4. Tarlo SM, Balmes J, Balkissoon R, et al. Diagnosis and management of work-related asthma: American College Of Chest Physicians Consensus Statement. Chest 2008;134(3 Suppl):1S-41S.

5. Meyer JD, Holt DL, Chen Y, Cherry NM, McDonald JC. SWORD '99: Surveillance of work-related and occupational respiratory disease in the UK. Occup Med 2001;51:204-8.

6. Rosenman KD, Reilly MJ, Kalinowski D. A state-based surveillance system for work-related asthma. J Occup Environ Med 1997;39:415-25.

7. Gannon PF, Burge PS. The SHIELD scheme in the West Midlands Region, United Kingdom. Midland Thoracic Society Research Group. Br J Ind Med 1993;50:791-6.

8. Hannaford-Turner K, Elder D, Sim MR, Abramson MJ, Johnson AR, Yates DH. Surveillance of Australian workplace Based Respiratory Events (SABRE) in New South Wales. Occup Med 2010;60:376-82.
The British Columbia Registry and PROPULSE (both modelled on SWORD), both of which were implemented in Canada in the early 1990s, did not progress beyond their pilot phase. Similar to these surveillance programs, our study encountered the challenge of a low participation rate, with less than $15 \%$ of invited physicians agreeing to join the reporting network. Despite a slow initial uptake, the reporting rate of participating physicians in the OWRAS Network continues to be greater than $80 \%$. Aside from a lower than ideal participation rate, these surveillance programs demonstrated the regional differences in exposure agents (as linked to industry). For example, the most frequently suspected causative agent of WRA reported to the British Columbia Registry was red cedar dust, while other highly reactive chemicals were most frequently reported to the OWRAS Network not isocyanates as reported by others.

Similar to other studies, the major limitation of our study was the low participation rate. With only $15 \%$ of invited physicians participating in the reporting system, we cannot be confident that the data collected would be generalizable to the incidence of cases seen by all physicians in Ontario. Although enlisting a sufficient number of reporting physicians remains problematic, the OWRAS Network has shown that it is feasible to establish and implement a voluntary reporting system for WRA in Ontario as a mechanism for physician reporting; however, the long-term sustainability of such a network is currently unknown.

ACKNOWLEDGEMENTS: The authors thank all of the physicians in Ontario who participated in the project by reporting monthly cases; Jovanka Vasilevska-Ristovska who assisted in the monthly follow up with physicians and data entry; Dr Sidney Siu, Hal de Lair and Dr Itamar E Tamari who provided invaluable help with recruiting physicians in Ontario to participate, and provided guidance for the design of the project; and Dr Catherine Lemière who contributed to both the conception and design of the project.

9. Ameille J, Pauli G, Calastreng-Crinquand A, et al. Reported incidence of occupational asthma in France, 1996-99: The ONAP programme. Occup Environ Med 2003;60:136-41.

10. Provencher S, Labreche FP, De Guire L. Physician based surveillance system for occupational respiratory diseases: The experience of PROPULSE, Quebec, Canada. Occup Environ Med 1997;54:272-6.

11. Contreras GR, Rousseau R, Chan-Yeung M. Occupational respiratory diseases in British Columbia, Canada in 1991. Occup Environ Med 1994;51:710-2.

12. Occupational Health and Safety Act. In: Revised Statutes of Ontario, 1990, Chapter 0.1, Section 52(2). <www.e-laws.gov.on.ca/ $\mathrm{html} /$ statutes/english/elaws_statutes_90o01_e.htm>

(Accessed on August 24, 2011).

13. Dillman D. Mail and Telephone Surveys: The Total Design Method. New York: Wiley, 1978.

14. Statistics Canada. National occupational classification for statistics (NOC-S) 2006. Ottawa: Minister of Industry (CA) Catalogue no. 12-583-XIE, 2007:648.

15. Kennedy S, Le Moual N, Choudat D, Kauffmann F. Development of an asthma-specific job exposure matrix and its application in the French epidemiological study of the genetics and environment of asthma (EGEA). Occup Environ Med 2000;57:635-41.

16. Bates DV, Gotsch AR, Brooks S, Landrigan PJ, Hankinson JL, Merchant JA. Prevention of occupational lung disease. Chest 1992;102(3 Suppl):257S-76S. 


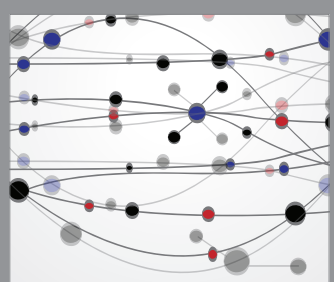

The Scientific World Journal
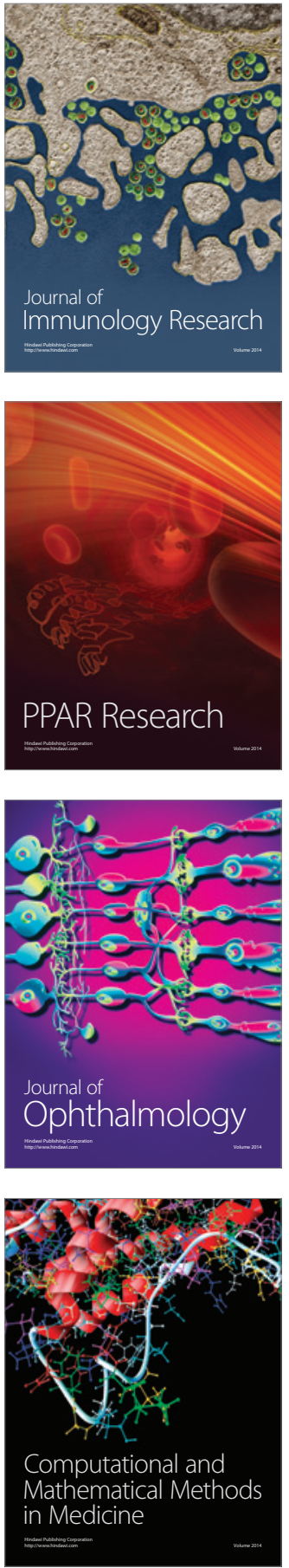

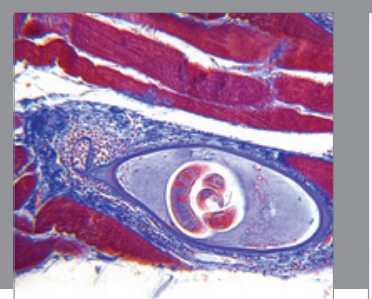

Gastroenterology Research and Practice

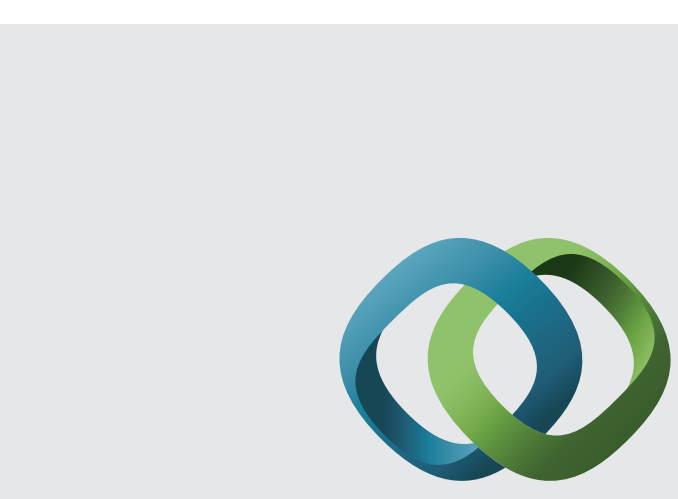

\section{Hindawi}

Submit your manuscripts at

http://www.hindawi.com
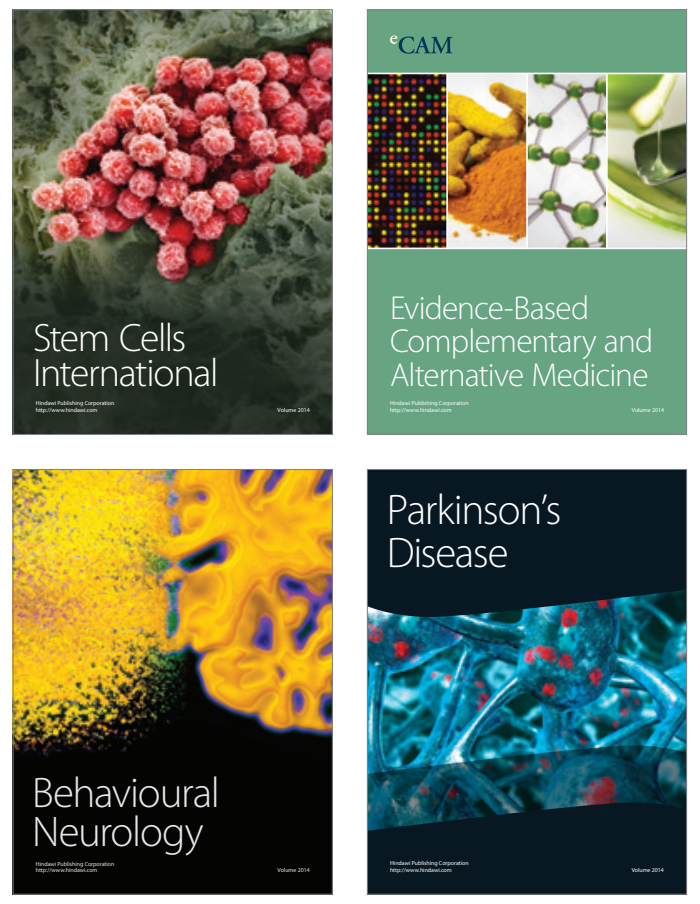
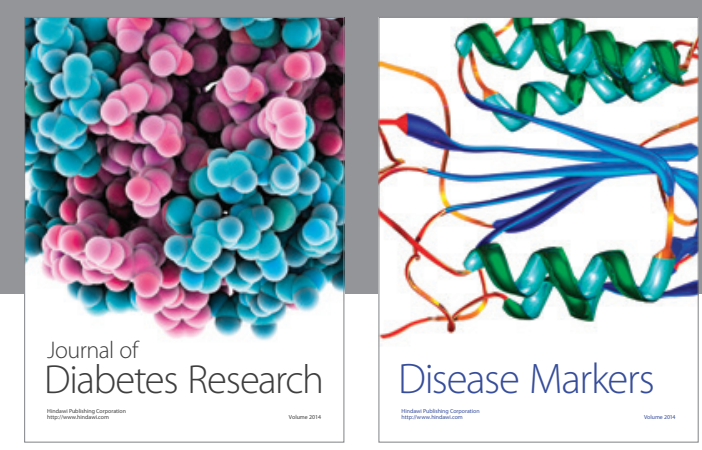

Disease Markers
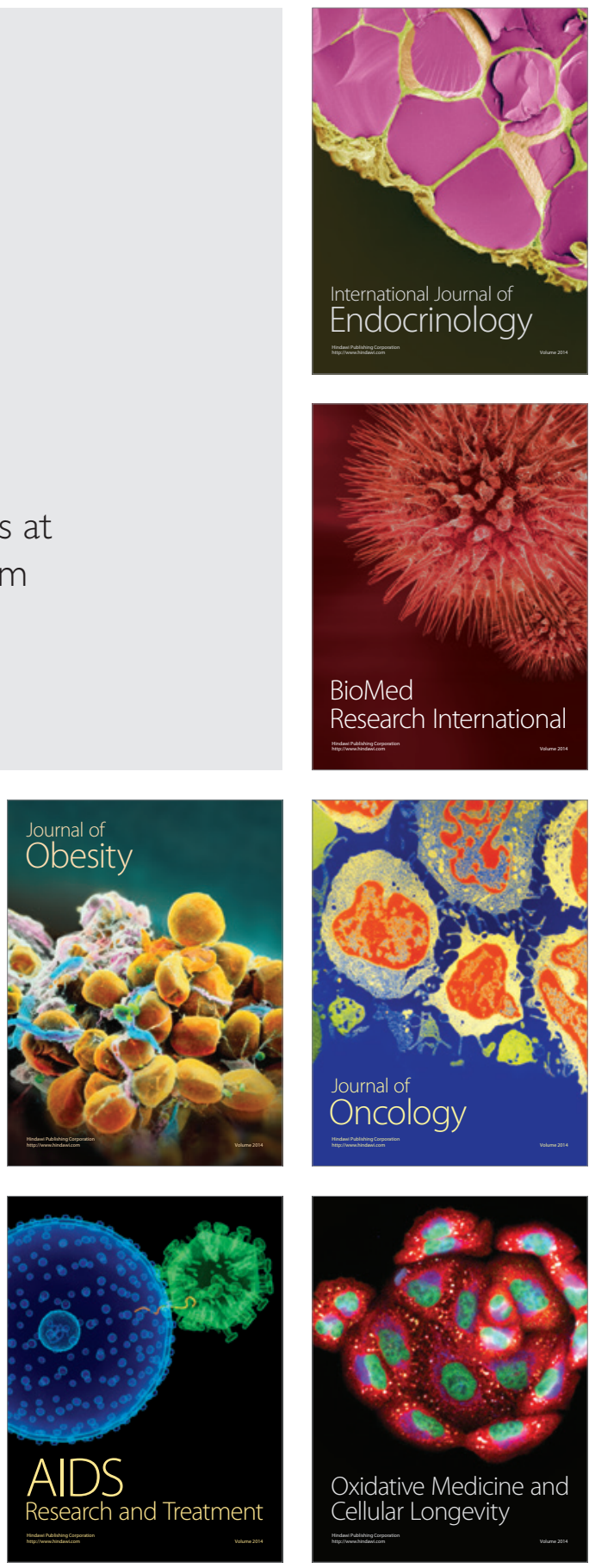